\title{
ANALISIS PERTUMBUHAN DAN PRODUKSI KEDELAI YANG DIBERI PERLAKUAN DENGAN EKSTRAK SENTANG (Azadirachta excelsa (Jack)) DAN MINDI (Melia azedarach L.)
}

\author{
Analysis of Growth and Soybean Production Treated by Sentang (Azadirachta Excelsa (Jack)) and \\ Mindi (Melia Azedarach L.) Extract
}

Rummi Azahra Gumilar $^{1 *}$, Nurheni Wijayanto ${ }^{2}$, Arum Sekar Wulandari ${ }^{2}$

(Diterima Agustus 2019/Disetujui Oktober 2020)

\begin{abstract}
Allelopathy interaction can occur between Azadirachta excelsa or Melia azedarach with soybean plants which is planted as intercrops in agroforestry system. The objectives of this study were to analyze the effect of root, leaf, and twig ectracts of Azadirachta excelsa and Melia azedarach on growth and production of soybean. This study was conducted in open fields using a split-split plot design inside randomized block design. The main plot was the plant species as extract materials consisted of Azadirachta excelsa and Melia Azedarach. The subplot was the part of the plant consisted of root, leaf, and twig. Sub-subplot was the concentration of the extract consisted of four levels, $0 \%$ (control), $1.25 \%, 2.5 \%$, and $5 \%$. Each treatment was repeated for 3 time. Result of this study showed that the root, leaf and twig extracts of A. excelsa and M. azedarach did not give significant effect to the height growth, dry weight, as well as soybean production.
\end{abstract}

Key words: agroforestry, allelopathy, growth, production

\section{PENDAHULUAN}

Agroforestri merupakan sistem penggunaan lahan terpadu yang mengkombinasikan pepohonan dengan tanaman pertanian atau ternak. Konsepnya merupakan penyatuan karakter tanaman yang berbeda di dalam suatu lahan. Agroforestri memungkinkan pemanfaatan lahan yang lebih optimal, peningkatan kesuburan lahan dan bahkan produksi kayu dan tanaman sela yang tinggi jika dikelola dengan tepat. Selain itu agroforestri juga dinilai sebagai usaha yang layak secara finansial dan dapat menghasilkan panen harian, mingguan, bulanan dan tahunan, bahkan untuk jangka waktu yang lebih panjang (Darusman 2012).

Sentang dan mindi merupakan jenis yang potensial untuk dikembangkan dalam sistem agroforestri. Sentang merupakan jenis pohon yang cepat tumbuh dan memiliki tajuk kerucut dengan arsitektur pohon yang seimbang, sehingga potensial dikembangkan dengan sistem agroforestri (Wibowo 2012). Di Malaysia dan Thailand, sentang telah dikembangkan secara luas untuk hutan tanaman dan sistem agroforestri. Sementara itu mindi termasuk golongan tanaman yang mudah tumbuh pada berbagai kondisi tanah dan tidak memerlukan perawatan yang intensif. Menurut Pramono et al. (2008), pohon mindi banyak ditemukan di lahan masyarakat di Jawa Barat sebagai bagian dari sistem pertanaman campuran.

\footnotetext{
${ }^{1}$ Mahasiswa Program Studi Silvikultur Tropika, Sekolah Pascasarjana Institut Pertanian Bogor

* Penulis korespondensi: e-mail: azahrarummi@gmail.com

${ }^{2}$ Dosen Departemen Silvikultur, Fakultas Kehutanan Institut Pertanian Bogor
}

Interaksi antar tanaman dalam sistem agroforestri merupakan hal yang tidak dapat dihindari. Salah satunya adalah interaksi alelopati. Sentang dan mindi memiliki kekurangan karena mengandung zat alelopati dalam jaringan tubuhnya. Alelopati dapat menghambat pertumbuhan dan perkembangan tanaman lain melalui zat alelokimia, yaitu metabolit sekunder yang bersifat racun bagi tanaman lain dan lingkungan sekitarnya (Einhellig 1996). Interaksi alelopati dapat terjadi antara tanaman sentang atau mindi dengan tanaman kedelai yang ditanam sebagai tanaman sela dalam sistem agroforestri.

Sebagian besar interaksi alelopati akan memberikan pengaruh yang merugikan dari satu tanaman terhadap tanaman lain. Munculnya pengaruh yang menguntungkan biasanya dianggap sebagai kebetulan atau ketidaksengajaan sehingga sering diabaikan. Menurut Li et al. (2010) senyawa alelokimia dapat menghambat pertumbuhan akar, pembelahan sel dan perubahan struktur sel, yang pada akhirnya akan menghambat pertumbuhan tanaman secara keseluruhan. Alelokimia mempengaruhi pertumbuhan dan perkembangan tumbuhan melalui beberapa cara di antaranya mempengaruhi kerja hormon dan enzim di dalam tumbuhan, mempengaruhi penyerapan hara, fotosintesis dan respirasi dan menghambat mekanisme penting lainnya di dalam tumbuhan. Oleh karena itu perlu dilakukan penelitian mengenai pengaruh alelopati tanaman sentang dan mindi terhadap tanaman kedelai. Tujuan penelitian ini adalah menganalisis pengaruh pemberian ekstrak sentang dan mindi terhadap pertumbuhan dan produksi tanaman kedelai. 


\section{METODE PENELITIAN}

\section{Waktu dan Tempat Penelitian}

Penelitian dilaksanakan pada bulan Juni sampai dengan September 2016 di Persemaian Permanen Dramaga, Bogor.

\section{Prosedur Penelitian}

Penelitian ini dilaksanakan dengan tahapan-tahapan sebagai berikut:

\section{Persiapan Bahan Ekstrak}

Bahan ekstrak berupa daun, akar, ranting sentang dan mindi diperoleh dari tegakan berumur dua tahun yang ditanam di hutan rakyat di daerah Cikabayan, Darmaga. Untuk mendapatkan ekstrak bahan dengan konsentrasi $10 \%(\mathrm{w} / \mathrm{v})$, bahan tanaman yang sudah dikeringkan sebanyak $10 \mathrm{~g}$ dicampur dengan $100 \mathrm{~mL}$ alkohol 70\%. Ekstrak dikocok selama 24 jam dengan kecepatan $150 \mathrm{rpm}$ pada temperatur ruang $\left(25-27^{\circ} \mathrm{C}\right)$, kemudian disaring dan didiamkan sampai alkoholnya menguap. Residu ekstrak yang tersisa dijadikan sebagai larutan stok dengan menambahkan aquades sebanyak $100 \mathrm{~mL}$ dan disaring lagi dengan kertas saring. Ekstrak dengan konsentrasi $1.25 \%, 2.5 \%$ dan $5 \%$ diperoleh dengan cara mengencerkan larutan stok (Lungu et al. 2011).

\section{Persiapan Media dan Penanaman}

Media tanam yang digunakan adalah tanah yang diperoleh dari sekitar persemaian permanen. Tanah yang digunakanz dianalisis sifat kimianya di Laboratorium Departemen Ilmu Tanah dan Sumberdaya Lahan Fakultas Pertanian IPB. Tanah kemudian dimasukkan dalam polibag ukuran $40 \mathrm{~cm}$ x $40 \mathrm{~cm}$, kemudian dibuat lubang tanam sedalam 2-3 cm. Benih kedelai ditanam sebanyak 4 butir benih ke dalam lubang tanam lalu ditutup dengan tanah.

\section{Pemeliharaan dan Aplikasi Larutan Ekstrak}

Pemeliharaan dilakukan dengan penyiraman setiap hari sampai 14 HST (hari setelah tanam) dan secukupnya sesuai kebutuhan setelahnya. Penyulaman dilakukan pada 7 HST untuk menyeragamkan pertumbuhan. Setelah 14 HST, dilakukan penjarangan dengan menyisakan satu tanaman/polibag. Pemberian ekstrak sentang dan mindi pada setiap tanaman dilakukan setiap 3 hari sekali mulai tanaman berumur 14 HST sampai dengan umur panen. Banyaknya ekstrak diberikan ialah $10 \mathrm{~mL}$ per polibag (Solichatun dan Nasir 2002).

\section{Pengukuran Tanaman Kedelai}

Pertumbuhan tanaman kedelai diketahui dengan mengamati variabel tinggi tanaman, bobot basah tanaman, bobot kering tajuk dan bobot kering akar (Susanto dan Sundari 2011). Tinggi tanaman diukur dari bagian pangkal sampai dengan titik tumbuh tanaman, dan diamati setiap minggu sekali mulai 2 MST sampai dengan 7 MST. Pengukuran bobot basah, bobot kering tajuk, bobot kering akar, nodulasi dan perakaran tanaman kedelai dilakukan pada 7 MST atau pada saat akhir masa vegetatif. Bobot kering tajuk dan bobot kering akar didapatkan dengan mengeringkan tanaman contoh pada suhu $70{ }^{\circ} \mathrm{C}$ selama $3 \times 24$ jam.

Peubah nodulasi kedelai yang diamati adalah jumlah bintil akar dan persentase bintil akar efektif (Fitri et al 2003). Bintil akar yang efektif dapat dilihat dari warnanya, yaitu apabila dipecah akan mengeluarkan cairan berwarna merah muda.

\section{Panen}

Kedelai yang telah siap panen memiliki ciri yaitu daun (90-95\%) sudah menguning kecoklatan lalu gugur, batang sudah kering dan berwarna kuning agak coklat dan gundul, buah kuning kecoklatan dan retak-retak, atau polong sudah kelihatan tua. Panen dilakukan pada saat kedelai berumur 12 minggu setelah tanam (MST).

\section{Analisis Kandungan Klorofil dan Hara}

Analisis kandungan klorofil menggunakan 2 contoh daun/perlakuan. Daun yang diambil adalah daun yang sudah terbuka secara sempurna yaitu pada umur 7 MST. Analisis kandungan klorofil dilakukan di Laboratorium Balai Penelitian Tanaman Rempah dan Obat.

Analisis kandungan hara menggunakan 3 sampel daun/perlakuan. Sampel daun kemudian dihaluskan dan dikompositkan untuk selanjutnya dianalisis di laboratorium untuk mendapatkan kandungan haranya. Serapan hara dihitung dengan menggunakan rumus (Agung dan Rahayu 2004):

Serapan hara $=$ bobot kering daun $\mathrm{x}$ kandungan hara

\section{Komponen Hasil}

Pengukuran komponen hasil dilakukan setelah tanaman kedelai siap dipanen yaitu pada saat umur 12 MST. Pengukuran komponen hasil terdiri atas persen hidup kedelai, umur panen (HST), jumlah buku produktif, jumlah polong per tanaman, jumlah polong berisi per tanaman, jumlah polong hampa, dan bobot biji kering per tanaman $(\mathrm{g})$.

\section{Rancangan Percobaan}

Penelitian ini menggunakan rancangan petak-petak terpisah (split-split plot) dalam rancangan lingkungan rancangan acak kelompok (RAK). Petak utamanya adalah jenis tanaman terdiri atas 2 taraf yaitu sentang dan mindi. Anak petak adalah bagian tanaman yang terdiri atas akar, daun dan ranting sentang dan mindi. Anakanak petak adalah konsentrasi ekstrak yang terdiri atas 4 taraf yaitu $0 \%$ (kontrol), $1.25 \%, 2.5 \%$, dan $5 \%$. Setiap perlakuan diulang sebanyak 3 kali.

\section{Analisis Data}

Data diolah dengan menggunakan software SAS 9.1 portable. Untuk mengetahui pengaruh perlakuan dalam penelitian ini, dilakukan sidik ragam (ANOVA) dan bila terdapat pengaruh yang signifikan pada variabel penelitian, maka analisis dilanjutkan dengan uji jarak berganda Duncan. 


\section{HASIL DAN PEMBAHASAN}

\section{Analisis Media Penelitian}

Informasi mengenai sifat kimia tanah sangat penting karena dapat menggambarkan tingkat kesuburan tanah. Data sifat kimia tanah disajikan pada Tabel 1.

\section{Respon Fisiologis}

Berdasarkan Gambar 1 kandungan klorofil tertinggi tanaman kedelai terdapat pada kontrol. Hasil penelitian menunjukkan peningkatan konsentrasi ekstrak yang diberikan tidak mengakibatkan penurunan kandungan klorofil.

\section{Produksi Kedelai}

Respon serapan hara tanaman kedelai terhadap pemberian ekstrak sentang dan mindi dapat dilihat pada Gambar 3. Tanaman kedelai dengan pemberian ekstrak akar dan ranting sentang pada berbagai konsentrasi menunjukkan tingkat serapan hara yang lebih rendah dibandingkan kontrol. Namun tanaman kedelai dengan pemberian ekstrak daun sentang memiliki tingkat serapan hara yang lebih tinggi dibandingkan kontrol meskipun perbedaannya tidak terlalu jauh. Tingkat serapan hara tanaman kedelai dengan pemberian ekstrak akar dan ranting mindi lebih rendah dibandingkan dengan kontrol. Sementara tanaman kedelai dengan pemberian ekstrak daun mindi memiliki tingkat serapan hara yang lebih tinggi dibandingkan dengan kontrol.

Tabel 1 Hasil analisis sifat kimia tanah

\begin{tabular}{lcr}
\hline \multicolumn{1}{c}{ Parameter } & Satuan & \multicolumn{1}{c}{ Nilai } \\
\hline $\mathrm{pH}$ & & 4.52 \\
$\mathrm{~N}$ & $\%$ & 0.07 \\
P tersedia & $\mathrm{ppm}$ & 5.02 \\
P total & $\mathrm{ppm}$ & 136.12 \\
$\mathrm{~K}$ & $\mathrm{cmol} / \mathrm{kg}$ & 0.17 \\
$\mathrm{KTK}$ & $\mathrm{cmol} / \mathrm{kg}$ & 13.47 \\
$\mathrm{Al}$ & $\mathrm{cmol} / \mathrm{kg}$ & 4.77 \\
Tekstur & & \\
$\quad$ Pasir & $\%$ & 7.41 \\
$\quad$ Debu & $\%$ & 18.62 \\
$\quad$ Liat & $\%$ & 73.97 \\
\hline
\end{tabular}

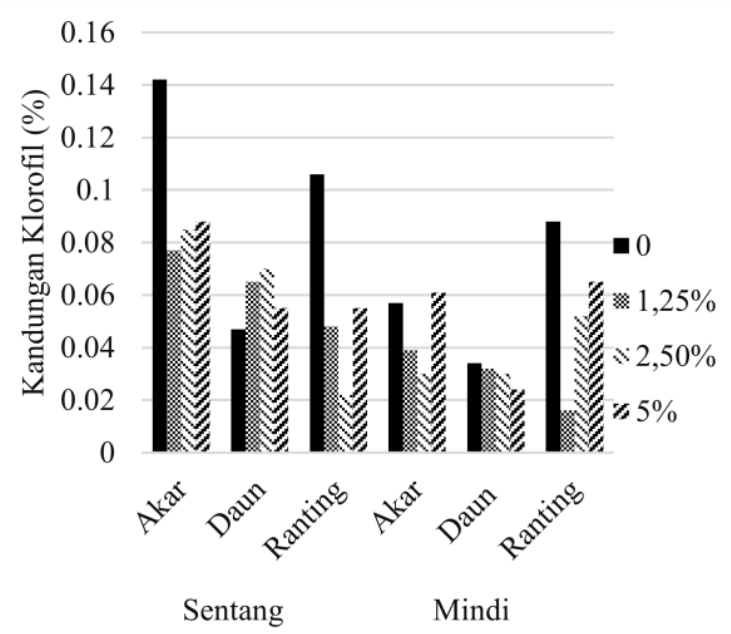

Gambar 1Kandungan klorofil tanaman kedelai dengan perlakuan ekstrak sentang dan mindi

\section{Pertumbuhan Kedelai}

Pemberian ekstrak sentang dan mindi tidak memberikan pengaruh yang nyata terhadap tinggi tanaman dan bobot kering total kedelai. Tabel 2 menunjukkan tinggi tanaman dan bobot kering total kedelai dengan pemberian ekstrak sentang dan mindi.

\section{Nodulasi Kedelai}

Tabel 3 menunjukkan jumlah bintil akar yang terbentuk pada tanaman kedelai dengan perlakuan ekstrak mindi. Jumlah bintil akar terbanyak ditemukan pada tanaman kontrol dengan persentase bintil akar efektif sebesar $57.89 \%$.

\section{Produksi Kedelai}

Hasil analisis ragam menunjukkan bahwa pemberian ekstrak akar, daun dan ranting sentang dan mindi tidak memberikan pengaruh yang nyata terhadap jumlah buku produktif, jumlah polong isi, jumlah polong hampa dan bobot biji kering per tanaman (Tabel 4).

Berdasarkan Tabel 5, produksi tanaman kedelai pada penelitian ini jauh lebih rendah dari standar yang ditetapkan oleh Badan Penelitian dan Pengembangan Tanaman Pertanian.

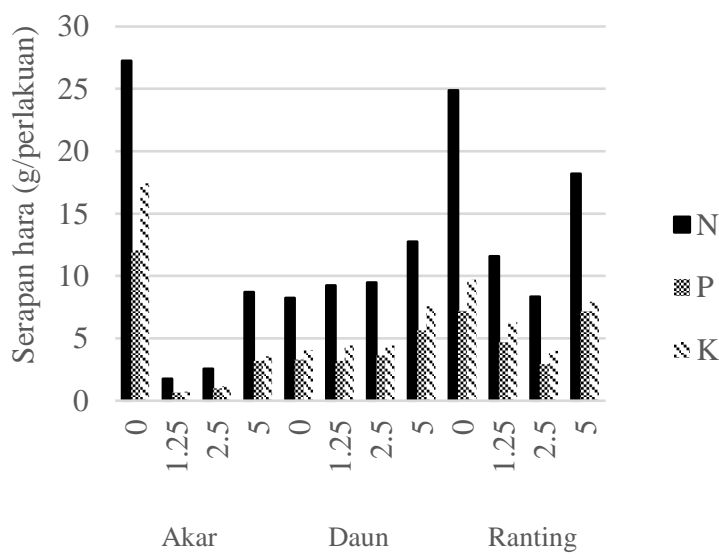

(a)

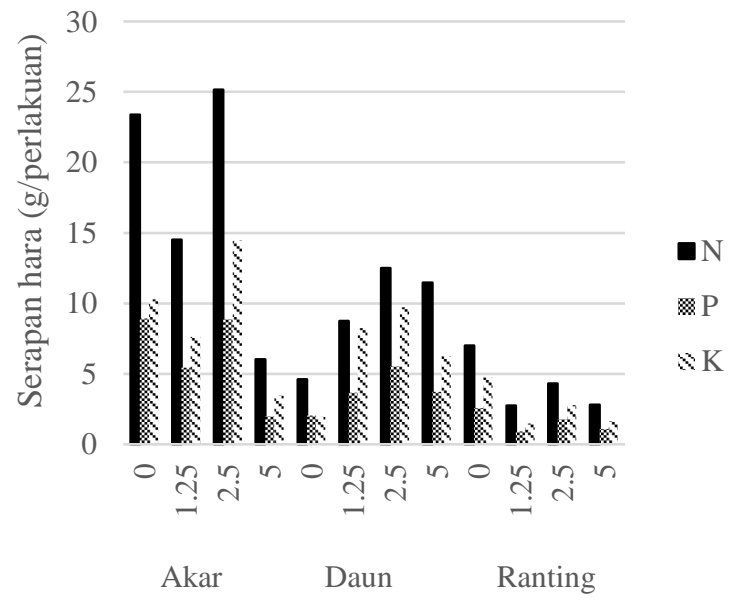

(b)

Gambar 3Serapan hara tanaman kedelai dengan perlakuan ekstrak: a) Sentang; b) Mindi 


\section{Respon Fisiologis}

Klorofil merupakan pigmen fotosintesis yang paling utama, yang memungkinkan tanaman untuk membuat makanannya sendiri. Sintesis klorofil dipengaruhi oleh cahaya, gula atau karbohidrat, air, temperatur, faktor genetik, unsur-unsur hara seperti $\mathrm{N}, \mathrm{Mg}, \mathrm{Fe}, \mathrm{Mn}, \mathrm{Cu}, \mathrm{Zn}$,
S dan O (Hendriyani dan Setiari 2009). Berdasarkan penelitian Yang et al. (2002), semakin tinggi konsentrasi zat alelopati yang diberikan pada tanaman maka semakin besar kemampuan reduksi kandungan klorofilnya. Einhellig (1996) menyatakan efek utama dari senyawa alelopati adalah pada membran plasma. Gangguan ini

Tabel 2 Pengaruh pemberian ekstrak akar, daun dan ranting sentang dan mindi terhadap tinggi tanaman kedelai

\begin{tabular}{|c|c|c|c|c|c|}
\hline \multirow{2}{*}{ Bagian tanaman } & \multirow{2}{*}{ Konsentrasi (\%) } & \multicolumn{2}{|c|}{ Tinggi kedelai $(\mathrm{cm})$} & \multicolumn{2}{|c|}{ Berat kering total (g) } \\
\hline & & Sentang & Mindi & Sentang & Mindi \\
\hline \multirow[t]{4}{*}{ Akar } & 0.00 & $9.89^{\mathrm{a}}$ & $9.78^{\mathrm{a}}$ & $2.46^{\mathrm{a}}$ & $2.27^{\mathrm{a}}$ \\
\hline & 1.25 & $6.97^{\mathrm{a}}$ & $12.39^{\mathrm{a}}$ & $0.45^{\mathrm{a}}$ & $1.83^{\mathrm{a}}$ \\
\hline & 2.50 & $6.78^{a}$ & $12.00^{\mathrm{a}}$ & $0.60^{\mathrm{a}}$ & $2.50^{\mathrm{a}}$ \\
\hline & 5.00 & $6.67^{\mathrm{a}}$ & $12.20^{\mathrm{a}}$ & $0.77^{\mathrm{a}}$ & $1.24^{\mathrm{a}}$ \\
\hline \multirow[t]{4}{*}{ Daun } & 0.00 & $10.78^{\mathrm{a}}$ & $10.16^{\mathrm{a}}$ & $1.14^{\mathrm{a}}$ & $1.39^{\mathrm{a}}$ \\
\hline & 1.25 & $9.00^{\mathrm{a}}$ & $10.96^{\mathrm{a}}$ & $1.47^{\mathrm{a}}$ & $1.91^{\mathrm{a}}$ \\
\hline & 2.50 & $10.83^{\mathrm{a}}$ & $10.92^{\mathrm{a}}$ & $1.31^{\mathrm{a}}$ & $1.66^{\mathrm{a}}$ \\
\hline & 5.00 & $9.67^{\mathrm{a}}$ & $10.50^{\mathrm{a}}$ & $1.50^{\mathrm{a}}$ & $1.45^{\mathrm{a}}$ \\
\hline \multirow[t]{4}{*}{ Ranting } & 0.00 & $9.78^{\mathrm{a}}$ & $9.72^{\mathrm{a}}$ & $1.98^{\mathrm{a}}$ & $1.36^{\mathrm{a}}$ \\
\hline & 1.25 & $7.19^{\mathrm{a}}$ & $8.94^{\mathrm{a}}$ & $1.91^{\mathrm{a}}$ & $1.07^{\mathrm{a}}$ \\
\hline & 2.50 & $8.61^{\mathrm{a}}$ & $10.17^{\mathrm{a}}$ & $1.21^{\mathrm{a}}$ & $1.01^{\mathrm{a}}$ \\
\hline & 5.00 & $9.50^{\mathrm{a}}$ & $9.26^{\mathrm{a}}$ & $1.85^{\mathrm{a}}$ & $1.27^{\mathrm{a}}$ \\
\hline
\end{tabular}

Angka-angka yang diikuti oleh huruf yang sama pada kolom yang sama tidak berbeda nyata pada uji DMRT taraf $5 \%$.

Tabel 3 Jumlah bintil dan persentase bintil akar efektif tanaman kedelai dengan perlakuan ekstrak akar, daun dan ranting sentang dan mindi

\begin{tabular}{|c|c|c|c|c|c|}
\hline \multirow[t]{2}{*}{ Bagian tanaman } & \multirow[t]{2}{*}{ Konsentrasi (\%) } & \multicolumn{2}{|c|}{ Jumlah bintil akar } & \multicolumn{2}{|c|}{ Persentase bintil akar efektif (\%) } \\
\hline & & Sentang & Mindi & Sentang & Mindi \\
\hline \multirow{4}{*}{ Akar } & 0.00 & 5 & 3 & 80.00 & 33.33 \\
\hline & 1.25 & 0 & 1 & 0.00 & 100.00 \\
\hline & 2.50 & 2 & 1 & 0.00 & 100.00 \\
\hline & 5.00 & 0 & 3 & 0.00 & 100.00 \\
\hline \multirow[t]{4}{*}{ Daun } & 0.00 & 1 & 6 & 0.00 & 66.67 \\
\hline & 1.25 & 0 & 1 & 0.00 & 100.00 \\
\hline & 2.50 & 4 & 1 & 75.00 & 100.00 \\
\hline & 5.00 & 0 & 0 & 0.00 & 0.00 \\
\hline \multirow[t]{4}{*}{ Ranting } & 0.00 & 19 & 0 & 57.89 & 0.00 \\
\hline & 1.25 & 0 & 5 & 0.00 & 0.00 \\
\hline & 2.50 & 0 & 5 & 0.00 & 0.00 \\
\hline & 5.00 & 1 & 0 & 0.00 & 0.00 \\
\hline
\end{tabular}

Tabel 4 Pengaruh pemberian ekstrak akar, daun dan ranting sentang dan mindi terhadap hasil panen tanaman kedelai

\begin{tabular}{|c|c|c|c|c|c|c|}
\hline Jenis & $\begin{array}{l}\text { Bagian } \\
\text { tanaman }\end{array}$ & Konsentrasi (\%) & $\begin{array}{l}\text { Jumlah buku } \\
\text { produktif }\end{array}$ & $\begin{array}{c}\text { Jumlah polong } \\
\text { isi }\end{array}$ & $\begin{array}{c}\text { Jumlah polong } \\
\text { hampa }\end{array}$ & $\begin{array}{c}\text { Bobot biji kering/tanaman } \\
\text { (g) }\end{array}$ \\
\hline \multirow[t]{12}{*}{ Sentang } & \multirow[t]{4}{*}{ Akar } & 0.00 & 4.00 & 11.00 & 1.67 & 1.63 \\
\hline & & 1.25 & 1.67 & 2.17 & 0.17 & 0.36 \\
\hline & & 2.50 & 2.83 & 4.50 & 0.17 & 1.03 \\
\hline & & 5.00 & 1.83 & 2.33 & 0.33 & 0.42 \\
\hline & \multirow[t]{4}{*}{ Daun } & 0.00 & 3.83 & 4.83 & 0.17 & 0.91 \\
\hline & & 1.25 & 4.17 & 8.17 & 0.33 & 1.43 \\
\hline & & 2.50 & 4.83 & 7.33 & 0.50 & 1.20 \\
\hline & & 5.00 & 4.17 & 8.33 & 0.00 & 1.51 \\
\hline & \multirow[t]{4}{*}{ Ranting } & 0.00 & 4.67 & 12.83 & 0.67 & 3.45 \\
\hline & & 1.25 & 2.83 & 5.17 & 0.50 & 1.02 \\
\hline & & 2.50 & 3.00 & 4.50 & 0.50 & 0.63 \\
\hline & & 5.00 & 3.17 & 4.50 & 0.17 & 0.87 \\
\hline \multirow[t]{12}{*}{ Mindi } & \multirow[t]{4}{*}{ Akar } & 0.00 & 4.83 & 10.67 & 0.50 & 2.25 \\
\hline & & 1.25 & 2.50 & 2.67 & 0.17 & 0.46 \\
\hline & & 2.50 & 3.00 & 6.17 & 0.50 & 1.71 \\
\hline & & 5.00 & 5.17 & 8.83 & 0.33 & 1.62 \\
\hline & \multirow[t]{4}{*}{ Daun } & 0.00 & 3.17 & 3.83 & 0.33 & 1.34 \\
\hline & & 1.25 & 3.50 & 8.00 & 0.17 & 1.30 \\
\hline & & 2.50 & 4.50 & 8.00 & 0.00 & 1.63 \\
\hline & & 5.00 & 2.17 & 2.17 & 0.50 & 0.39 \\
\hline & \multirow{4}{*}{ Ranting } & 0.00 & 2.83 & 4.67 & 0.33 & 0.82 \\
\hline & & 1.25 & 1.83 & 2.33 & 0.00 & 0.49 \\
\hline & & 2.50 & 3.50 & 3.83 & 0.17 & 0.76 \\
\hline & & 5.00 & 4.33 & 9.83 & 0.17 & 1.37 \\
\hline
\end{tabular}

Angka-angka yang diikuti huruf yang sama pada kolom yang sama tidak berbeda nyata pada taraf uji 5\% (uji selang berganda Duncan). 
memberikan kontribusi terhadap sejumlah efek fisiologis yang menyebabkan penurunan pertumbuhan. Senyawa alelopati memberikan efek fisiologis berupa pengurangan kandungan klorofil pada tumbuhan dengan menghambat jalur biosintesis klorofil, atau merangsang degradasi klorofil, atau keduanya.

Hasil penelitian ini menunjukkan kandungan klorofil tanaman kontrol lebih banyak dibandingkan dengan tanaman kedelai yang diberi perlakuan ekstrak sentang dan mindi. Peningkatan konsentrasi ekstrak yang diberikan tidak mengakibatkan penurunan kandungan klorofil. Namun tidak dapat dipastikan rendahnya kandungan klorofil pada perlakuan ekstrak akar, daun dan ranting sentang dan mindi terjadi karena adanya efek alelopati.

Tanaman kedelai dengan pemberian ekstrak mindi memberikan respon serapan hara yang tidak berbeda jauh dengan kedelai yang diberi ekstrak sentang. Tingkat serapan hara tanaman dapat dinilai dengan melihat bobot keringnya. Bobot kering tanaman mencerminkan nutrisi tanaman karena tergantung pada fotosintesis. Hasil analisis ragam menunjukkan bahwa ekstrak sentang dan mindi tidak memberikan pengaruh nyata terhadap bobot kering tanaman kedelai. Hal ini berarti tingkat serapan hara kedelai tidak terganggu dengan pemberian ekstrak sentang dan mindi. Rendahnya tingkat serapan hara tanaman kedelai diduga disebabkan oleh adanya substansi toksik yang mengganggu metabolisme tanaman. Substansi toksik ini di antaranya adalah konsentrasi Al yang tinggi di dalam tanah. Berdasarkan hasil analisis sifat kimia tanah, media tanah yang digunakan dalam penelitian ini memiliki kandungan $\mathrm{Al}$ yang tergolong tinggi (Tabel 1). Aluminium menghambat penyerapan hara tanaman melalui modifikasi fisiologis dan biokimia terutama penurunan permeabilitas membran akar terhadap ion dan air (Russel 1988).

\section{Pertumbuhan dan Produksi Kedelai}

Pemberian ekstrak sentang dan mindi tidak memberikan pengaruh yang nyata terhadap semua peubah pertumbuhan dan produksi tanaman kedelai. Faktor curah hujan yang tinggi dan konsentrasi ekstrak yang rendah diduga menjadi penyebab utama hilangnya efek alelopati terhadap tanaman kedelai.

Hasil analisis komponen senyawa kimia akar, daun dan ranting tanaman sentang dan mindi menunjukkan bahwa tanaman sentang dan mindi mengandung zat alelopati. Efek alelopati yang ditimbulkan oleh suatu tanaman terhadap tanaman lain ditentukan oleh konsentrasi alelokimia yang dilepaskan ke lingkungan (Bhowik dan Inderjit 2003). Senyawa alelokimia yang terkandung dalam ekstrak sentang dan mindi sebagian besar memiliki sifat yang mudah terlarut dalam air. Oleh karena itu, faktor curah hujan yang tinggi menjadi salah satu penyebab hilangnya senyawa alelokimia dalam tanah karena mengalami pencucian. Menurut Sangheeta dan Baskar (2015), pencucian, proses fisiokimia dan penyerapan hara oleh tanaman merupakan faktor yang dapat mengurangi konsentrasi alelokimia di dalam tanah.

Kedelai merupakan salah satu tanaman yang mampu bersimbiosis dengan rhizobium membentuk bintil akar. Bintil akar digunakan tanaman kedelai untuk memfiksasi nitrogen yang digunakan untuk pertumbuhan. Hasil penelitian menunjukkan bahwa jumlah bintil akar tanaman kedelai lebih banyak pada kontrol dibandingkan dengan yang diberi perlakuan ekstrak sentang. Hal ini diduga disebabkan oleh kandungan ammonium carbamate yang terdapat dalam ekstrak sentang. Senyawa ini umumnya digunakan sebagai bahan baku pembuatan pupuk urea yang mampu menyediakan kebutuhan nitrogen bagi tanaman. Penambahan ekstrak sentang yang mengandung ammonium carbamate akan menurunkan penambatan $\mathrm{N}_{2}$ sejalan dengan jumlah nitrogen yang diserap. Pada perlakuan ekstrak mindi, bintil akar ditemukan hampir pada semua tanaman yang diberi larutan ekstrak kecuali pada perlakuan daun dan akar mindi konsentrasi $5 \%$.

Tabel 5 Perbandingan hasil kedelai per ha

\begin{tabular}{|c|c|c|c|c|}
\hline Jenis & Bagian tanaman & Konsentrasi & Bobot per ha (t/ha) & Rata-rata hasil (t/ha)* \\
\hline \multirow[t]{12}{*}{ Sentang } & Akar & 0.00 & 0.26 & \\
\hline & & 1.25 & 0.06 & \\
\hline & & 2.50 & 0.16 & \\
\hline & & 5.00 & 0.07 & \\
\hline & Daun & 0.00 & 0.15 & \\
\hline & & 1.25 & 0.23 & \\
\hline & & 2.50 & 0.19 & \\
\hline & & 5.00 & 0.24 & \\
\hline & Ranting & 0.00 & 0.55 & \\
\hline & & 1.25 & 0.16 & \\
\hline & & 2.50 & 0.10 & \\
\hline & & 5.00 & 0.14 & 15200 \\
\hline \multirow[t]{12}{*}{ Mindi } & Akar & 0.00 & 0.36 & $1.5-2.00$ \\
\hline & & 1.25 & 0.07 & \\
\hline & & 2.50 & 0.27 & \\
\hline & & 5.00 & 0.26 & \\
\hline & Daun & 0.00 & 0.21 & \\
\hline & & 1.25 & 0.21 & \\
\hline & & 2.50 & 0.26 & \\
\hline & & 5.00 & 0.06 & \\
\hline & Ranting & 0.00 & 0.13 & \\
\hline & & 1.25 & 0.08 & \\
\hline & & 2.50 & 0.12 & \\
\hline & & 5.00 & 0.22 & \\
\hline
\end{tabular}

*) Sumber: Balittan (2000) 
Jumlah bintil akar yang sedikit dengan efektivitas yang rendah salah satunya disebabkan oleh media tanam yang masam. $\mathrm{pH}$ tanah yang digunakan dalam penelitian ini adalah sebesar 4.52 (Tabel 1). Rhizobium dapat tumbuh dan berkembang dengan baik pada $\mathrm{pH}$ tanah 5.57.0. Keadaan tanah yang masam secara tidak langsung menyebabkan berkurangnya kolonisasi Rhizobium dalam tanah sehingga pembentukan bintil akar lebih sedikit. Pada tanah dengan $\mathrm{pH}$ rendah akar kedelai tidak dapat berkembang dan bintil akar tidak terbentuk dengan baik (Ritchie 1989). Kandungan alelopati pada ekstrak sentang dan mindi juga diduga dapat menghambat pembentukan bintil akar kedelai. Wibowo (1996) menyatakan bahwa kandungan alelopati pada rumput teki mampu menurunkan jumlah bintil akar efektif kedelai. Penurunan ini terlihat saat tanaman kedelai berumur 34 HST.

Produksi tanaman kedelai pada penelitian ini tidak dipengaruhi oleh perlakuan ekstrak akar, daun dan ranting sentang dan mindi, namun produktivitas kedelai lebih rendah dari standar yang ditetapkan. Hal ini diduga disebabkan oleh beberapa faktor seperti tingginya curah hujan saat pengisian polong, konsentrasi Al yang tinggi di dalam tanah dan rendahnya tingkat serapan hara tanaman kedelai.

Konsentrasi Al yang tinggi pada tanah masam merupakan faktor pembatas dalam produksi tanaman. Konsentrasi Al yang tinggi dapat menghambat pertumbuhan perakaran tanaman, merusak sel akar terutama pada ujung akar yang berperan aktif dalam penyerapan air dan unsur hara. Kemungkinan lain yang menyebabkan rendahnya produksi tanaman kedelai pada penelitian ini adalah kondisi tanah yang masam. Pada tanah yang masam unsur-unsur mikro menjadi lebih mudah larut dan beracun. Tingginya konsentrasi Al pada tanah masam juga mengakibatkan terhambatnya penyerapan unsur $\mathrm{P}$ karena difiksasi oleh $\mathrm{Al}$, padahal unsur $\mathrm{P}$ berperan dalam pembungaan dan pembuahan biji (Hardjowigeno 2007).

\section{SIMPULAN}

Tanaman kedelai dengan pemberian ekstrak akar dan ranting sentang pada berbagai konsentrasi menunjukkan kandungan klorofil dan tingkat serapan hara yang lebih rendah dibandingkan dengan kontrol.

Pemberian ekstrak akar, daun dan ranting sentang dan mindi tidak memberikan pengaruh nyata terhadap pertumbuhan tinggi, bobot basah dan bobot kering, dan produksi tanaman kedelai. Hal ini membuktikan bahwa senyawa alelopati yang terkandung dalam akar, daun dan ranting sentang dan mindi bukanlah faktor pembatas dalam agroforestri sentang dan mindi dengan tanaman kedelai. Selain karena faktor lingkungan, dengan pengelolaan lahan yang tepat pengaruh alelopati pada tanaman dan lingkungannya bisa dihindari.

\section{DAFTAR PUSTAKA}

Agung T, Rahayu AY. 2004. Analisis efisiensi serapan $\mathrm{N}$, pertumbuhan, dan hasil beberapa kultivar kedelai unggul baru dengan cekaman kekeringan dan pemberian pupuk hayati. Agrosains. 6(2): 7074.

[Balittan] Badan Penelitian dan Pengembangan Tanaman Pertanian. 2000. Teknologi produksi kedelai [internet]. [diunduh 2016 Des 20]. Tersedia pada: http://pustaka.litbang.deptan.go.id/agritek/ppua01 63.pdf.

Bhowmik PC, Inderjit. 2003. Challenges and opportunities in implementing allelopathy for natural weed management. Crop Prot. 22: 661671.

Darusman D. 2012. Kehutanan demi keberlanjutan Indonesia. Bogor (ID): IPB Press.

Einhellig FA. 1996. Interactions involving allelopathy in cropping systems. Agron J 88:886-893.

Fitri DA, Solichatun, Mudyantini W. 2003. Pengaruh ekstrak tanaman kacang hijau (Vigna radiata (L.) Wilczek.) terhadap pertumbuhan dan nodulasi tanaman kedelai (Glycine $\max$ (L.) Merr.). Biosmart 6(1): 24-28.

Hardjowigeno S. 2007. Ilmu Tanah. Jakarta: Akademika Pressindo.

Hendriyani IS, Setiari N. 2009. Kandungan klorofil dan pertumbuhan kacang panjang (Vigna sinensis) pada tingkat penyediaan air yang berbeda. J Sains \& Mat. 17(3):145-150.

Li ZH, Wang, Q, Ruan X, Pan CD, Jiang DA. 2010. Phenolics and plant allelopathy. Molecules 15: 8933-8952.

Lungu L, Popa CV, Morris J, Savoiu M. 2011. Evaluation of phytotoxic activity of Melia azedarach L. extracts on Lactuca sativa L. Romanian Biotechnological Letters 16(2): 6089 - 6095.

Pramono AA, Danu, Rohandi A, Royani H, Abidin AZ, Supardi E, Nurokhim N. 2008. Sebaran Potensi Sumber Benih jenis Potensial (Mindi) di Jawa Barat. Laporan Hasil Penelitian. Balai Penelitian Teknologi Perbenihan. Bogor.

Ritchie GSP. 1989. The chemical behaviour of aluminium, hydrogen and manganese in acid soils. p.1-49. In A.D. Robsonm (Ed.). Soil acidity and plant growth. Acad. Press. Harcourt Brace Jovanovich, Publishers.

Russel RS. 1988. Plant Root System. London: Mc Graw Hill Book Company.

Sangheeta C, Baskar P. 2015. Allelopathy in weed anagement: a critical review. African Journal of Agricultural Research 10(9): 1004-1015.

Solichatun, Nasir M. 2002. Alelopati intravarietas vigna radiata (1.) wilczek yang tumbuh pada ketersediaan air yang berbeda terhadap perkecambahan, pertumbuhan dan nodulasinya. Biosmart 4(2): $27-31$.

Susanto GW, Sundari T. 2011. Perubahan karakter agronomi aksesi plasma nutfah kedelai di lingkungan ternaungi. J Agron Indonesia 39(1):16.

Sutanto R. 2002. Penerapan Pertanian Organik: Pemasyarakatan dan Pengembangannya. Yogyakarta: Kanisius.

Wibowo DN. 1996. Effect of root and shoot extract of purple nutsedge (Cyperus rotundus L.) at different 
concentrations on root nodule formation, growth, and yield of soybean (Glycine $\max$ (L.) Merr.). Southeast Asia Regional Center for Tropical Biology, Bogor. Indonesia.

Wibowo ARP. 2012. Agroforestri sentang (Azadirachta excelsa Jack) dan sorgum (Sorghum bicolor L. Moench) [tesis]. Bogor: Institut Pertanian Bogor.
Yang C, Lee C, Chou C. 2002. Effect of three allelopathic phenolics on chlorophyll accumulation of rice (Oryza sativa) seedlings: I. inhibition of supplyorientation. Botanical Bulletin of Academica Sinica 120: 479-486. 